University of New Hampshire

University of New Hampshire Scholars' Repository

11-27-1999

\title{
Using the space-borne NASA scatterometer (NSCAT) to determine the frozen and thawed seasons
}

\author{
Steve Frolking \\ University of New Hampshire - Main Campus, steve.frolking@unh.edu \\ Kyle McDonald \\ California Institute of Technology \\ John Kimball \\ University of Montana, Missoula \\ S W. Running \\ University of Montana, Missoula \\ R Zimmermann \\ University of Bayreuth
}

Follow this and additional works at: https://scholars.unh.edu/earthsci_facpub

\section{Recommended Citation}

Frolking, S., K. C. McDonald, J. S. Kimball, J. B. Way, R. Zimmermann, and S. W. Running (1999), Using the space-borne NASA scatterometer (NSCAT) to determine the frozen and thawed seasons, J. Geophys. Res., 104(D22), 27895-27907, doi:10.1029/1998JD200093.

This Article is brought to you for free and open access by the Earth Sciences at University of New Hampshire Scholars' Repository. It has been accepted for inclusion in Earth Sciences Scholarship by an authorized administrator of University of New Hampshire Scholars' Repository. For more information, please contact Scholarly.Communication@unh.edu. 


\title{
Using the space-borne NASA scatterometer (NSCAT) to determine the frozen and thawed seasons
}

\author{
S. Frolking, ${ }^{1}$ K.C. McDonald, ${ }^{2}$ J.S. Kimball, ${ }^{3}$ J.B. Way, ${ }^{2}$ R. Zimmermann, ${ }^{4}$ \\ and S.W. Running ${ }^{3}$
}

\begin{abstract}
We hypothesize that the strong sensitivity of radar backscatter to surface dielectric properties, and hence to the phase (solid or liquid) of any water near the surface should make space-borne radar observations a powerful tool for large-scale spatial monitoring of the freeze/thaw state of the land surface, and thus ecosystem growing season length. We analyzed the NASA scatterometer (NSCAT) backscatter from September 1996 to June 1997, along with temperature and snow depth observations and ecosystem modeling, for three BOREAS sites in central Canada. Because of its short wavelength $(2.14 \mathrm{~cm})$, NSCAT was sensitive to canopy and surface water. NSCAT had $25 \mathrm{~km}$ spatial resolution and approximately twice-daily temporal coverage at the BOREAS latitude. At the northern site the NSCAT signal showed strong seasonality, with backscatter around $-8 \mathrm{~dB}$ in winter and $-12 \mathrm{~dB}$ in early summer and fall. The NSCAT signal for the southern sites had less seasonality. At all three sites there was a strong decrease in backscatter during spring thaw (4-6 dB). At the southern deciduous site, NSCAT backscatter rose from -11 to $-9.2 \mathrm{~dB}$ during spring leaf-out. All sites showed 1-2 dB backscatter shifts corresponding to changes in landscape water state coincident with brief midwinter thaws, snowfall, and extreme cold $\left(T_{\max }<-25^{\circ} \mathrm{C}\right)$. Freeze/thaw detection algorithms developed for other radar instruments gave reasonable results for the northern site but were not successful at the two southern sites. We developed a change detection algorithm based on first differences of 5-day smoothed NSCAT backscatter measurements. This algorithm had some success in identifying the arrival of freezing conditions in the autumn and the beginning of thaw in the spring. Changes in surface freeze/thaw state generally coincided with the arrival and departure of the seasonal snow cover and with simulated shifts in the directions of net carbon exchange at each of the study sites.
\end{abstract}

\section{Introduction}

The transition of the land surface from a frozen to a thawed state represents the closest analog to a biospheric on/off switch existing in nature. This transition strongly affects ecological trace gas dynamics, surface meteorological conditions, and landscape hydrologic activity. The timing of ecosystem freeze-up and thaw and thus the duration of both the growing and the dormant seasons for plants, can be expected to change with climatic change. A climatic warming will likely lead generally to earlier thaws, later freeze-ups, and a longer growing season. There is also a large range in interannual variability (up to 6 weeks or more) in the timing of freeze and thaw at a given location [e.g., Frolking et al., 1996].

The timing of spring thaw and the duration of the growing season are strongly linked to the carbon balance of boreal and arctic systems. In both empirical [Goulden et al., 1997] and

\footnotetext{
'Institute for the Study of Earth, Oceans, and Space and Department of Earth Sciences, University of New Hampshirc, Durham.

${ }^{2}$ Jet Propulsion Laboratory, California Institute of Technology, Pasadena.

${ }^{3}$ School of Forestry, University of Montana, Missoula.

${ }^{4}$ Bitöek, University of Bayreuth, Bayrcuth, Germany.

Copyright 1999 by the American Geophysical Union.

Paper number 1998JD200093.

0148-0227/99/1998JD200093\$09.00
}

process [Frolking et al., 1996; Frolking, 1997] boreal ecosystem modeling studies, earlier spring thaws led to significant increases in net carbon uptake. Eddy covariance carbon flux measurements have shown enhanced carbon uptake associated with earlier spring thaws in both temperate forest [Goulden et al., 1996] and boreal forest stands. At the Boreal Ecosystem-Atmosphere Study (BOREAS) southern aspen site, the transition of the ecosystem from a carbon source $(\sim 25 \mathrm{~kg} \mathrm{C} / \mathrm{ha} / \mathrm{d}$ loss $)$ to its maximum rate of carbon uptake ( $\sim 75 \mathrm{~kg} \mathrm{C} / \mathrm{ha} / \mathrm{d}$ uptake) occurs over a 10 day period in the spring of both 1994 and 1996 (data were not collected in 1995); an earlier spring at this site in 1994 yielded an additional $-0.67 \mathrm{Mg} \mathrm{C}$ net uptake compared with spring 1996 [Black et al., 1996; T.A. Black et al. unpublished data, 1996]. For this deciduous stand, the ecosystem transition from a carbon source to a carbon sink lagged soil thaw by about 5 weeks in both 1994 and 1996. At the BOREAS northern and southern black spruce sites the ecosystem's transition from carbon source to sink is coincident with snowmelt and soil thaw [Goulden et al., 1997; Jarvis et al., 1997; P.G. Jarvis et al. unpublished data, 1996]. Increased vegetation activity at high latitudes has been inferred from both the atmospheric $\mathrm{CO}_{2}$ concentration record [Keeling et al., 1996] and the advanced very high resolution radiometer (AVHRR) normalized difference vegetation index (NDVI) record [Myneni et al., 1997]. The 1981-1990 surface temperature record shows a significant warming trend $\left(\sim 2^{\circ}-4^{\circ} \mathrm{C}\right)$ for the late winter/early spring for northern latitudes $\left(>45^{\circ} \mathrm{N}\right)$ [Myneni et al., 1997]. Soil temperature simulations from 1976 to 1996 for 
boreal forest stands, using the model of Frolking et al. [1996], show 6 to 7-week ranges in the timing of soil thaw at $3 \mathrm{~cm}$.

There have been a number of applications of microwave sensors to detect freeze/thaw transitions in terrestrial ecosystems. The microwave backscatter signature of a landscape is controlled by the landscape's structure and dielectric properties [Elachi, 1987]. The interaction of an electric field with a dielectric material has its origin in the response of charged particles to the applied field. The displacement of these particles from their equilibrium positions gives rise to induced dipoles that respond to the applied field. In addition, polar materials contain permanent dipoles caused by the asymmetric charge distribution within the molecules themselves. Consisting of highly polar molecules, liquid water exhibits a dielectric constant that dominates the microwave dielectric response of natural landscapes [Kraszewski, 1996]. As water freezes, the molecules become bound in a crystalline lattice, and the dielectric constant decreases substantially. For vegetated landscapes that undergo freeze/thaw transitions, this drop in dielectric constant results in a large decrease in L-band (15 $30 \mathrm{~cm}$ wavelength) and C-band (3.75 - $7.5 \mathrm{~cm}$ wavelength) backscatter [Way et al., 1994; Way et al., 1997]. In addition, microwave sensors are active systems providing their own illumination source and receiving that which is scattered from the surface, thus providing observations day and night, independent of seasonal Sun angles. Also, microwave sensors operate at relatively long wavelengths thereby "seeing through" clouds, aerosols, and smoke, which obscure the land surface at optical wavelengths. Continuous access to surface state is available 365 days a year and in any weather; actual coverage is therefore defined by a mission's orbit design.

Studies using truck-mounted scatterometers have shown that radar backscatter from frozen ground and frozen vegetation is significantly different than the radar backscatter from thawed ground and vegetation [Ulaby et al., 1982]. Wegmuller [1990] measured a 3-4 dB drop in radar backscatter from bare soils during day-night freeze/thaw cycles. Backscatter change resulting from freezing and thawing was first observed in radar image data in a series of aircraft radar data sets that were acquired over the Bonanza Creek Experimental Forest, a Long-Term Ecological Research (LTER) site near Fairbanks, Alaska, in March 1988 [Way et al., 1994]. During the time period over which the imaging radar data were collected, temperatures ranged from unseasonably warm (up to $9^{\circ} \mathrm{C}$ ) to well below freezing $(-8$ to $-15^{\circ} \mathrm{C}$ ), and the free water in the trees changed from a liquid to a solid phase. These imaging radar data showed a 4 to $6 \mathrm{~dB}$ decrease in the radar backscatter of the forest stands with freezing.

With the launch of ERS-1 in 1991 an intensive study of the fall freeze transition was carried out in Alaska [Rignot et al., 1994]. ERS-1 C-band images were acquired of the Tanana River floodplain forests. Canopy and soil temperatures and meteorological data were collected in three representative stands: black spruce, white spruce, and balsam poplar. The data show that a $3 \mathrm{~dB}$ drop in backscatter occurs during the trees' transition from a thawed to a frozen state. The results of this work were applied on a landscape scale by Rignot and Way [1994]. Transects of $200 \mathrm{~m}$ resolution ERS-1 radar data which crossed Alaska from north to south were collected from August to November 1991. Freezing, as observed in the image transects, was consistent with meteorological data collected along the transects; the data show that (as expected) freezing occurs first in the high-latitude and high-altitude regions. In the autumn, backscatter decreased to reflect frozen conditions and remained stable during early snowpack accumulation [Rignot and Way, 1994].

ERS-1 imaging radar data from the 1994 BOREAS experiment showed a two-stage shift in backscatter, the first coincident with observed soil thaw in March and the second with canopy thaw in May [Way et al., 1997]. Tree bole and soil temperature data at the southern black spruce site showed a transition from completely frozen soil to the onset of soil thaw on day of year 60 . The water in the tree stems thawed on day of year 100 and remained at or above $0^{\circ} \mathrm{C}$ after this date. The ERS-1 data show a significant rise in backscatter between day of year 60 and 63 , and again between day of year 78 and 102 [Way et al., 1997]. These shifts in ERS-1 backscatter were concurrent with ecosystem model simulations of shifts in net ecosystem exchange of carbon dioxide with the atmosphere [Way et al., 1997; Kimball et al., 1997; Frolking et al., 1996].

Boehnke and Wismann [1997] used the ERS-1 scatterometer to detect soil thaw in Siberia, resampling backscatter data from March 1 to July 1, 1993, to a $50 \times 50 \mathrm{~km}$ grid and computing a 3-day average backscatter. They proposed as an ERS scatterometer freeze/thaw detection algorithm, that the landscape thaws (freezes) when two consecutive backscatter values exceed (drop below) the average of all July and all February backscatter values [Boehnke and Wismann, 1997]. By requiring two consecutive signals above or below the threshold value, the algorithm will not be triggered by brief freeze/thaw events or spikes in the data. It also will not detect or interpret signals like the large drop in backscatter (below the frozen winter values) which occurred at their northern location.

In this paper we explore the usefulness of radar backscatter data from NSCAT for detecting boreal ecosystem freeze/thaw transitions at sites in the BOREAS area in central Canada. NSCAT had a broader swath width than the ERS-1 scatterometer, providing coverage with coarser spatial resolution $(25 \mathrm{~km})$ and higher temporal resolution (twice daily). NSCAT had a higher frequency (shorter wavelength) than the ERS-1 SAR and scatterometer, providing a different sensor configuration and thus somewhat different scattering physics.

\section{Sites and Data}

\subsection{Field Sites}

We chose three field sites from the BOREAS program for our study: the northern old black spruce (NOBS) site near Thompson, Manitoba $\left(55.9^{\circ} \mathrm{N}, 98.5^{\circ} \mathrm{W}\right)$, the southern old black spruce (SOBS) site near Nipawin, Saskatchewan $\left(54.0^{\circ} \mathrm{N}, 105.1^{\circ} \mathrm{W}\right)$, and the southern old aspen (SOA) site in Prince Albert National Park, Saskatchewan $\left(53.6^{\circ} \mathrm{N}\right.$, $106.2^{\circ} \mathrm{W}$ ). All three sites had eddy covariance flux towers operating during the BOREAS program in 1994 and 1996, and the towers at NOBS and SOA continue to operate. Since the operation period for NSCAT was September 1996 through June 1997, and thus generally outside the BOREAS field campaign periods and beyond the BOREAS meteorological network operational period [Sellers et al., 1997], we have taken weather data from two stations operated by the Canadian Atmospheric Environment Service (AES) 
(Thompson, Manitoba, and Nipawin, Saskatchewan) which have reported 1996 and 1997 data. These data were obtained from the National Climate Data Center Summary of the Day, First-Order TD-3210 database (http://www4.ncdc.noaa.gov/ol/documentlibrary/datasets.html\#TD3210). These stations reported daily maximum and minimum temperatures, daily total precipitation, and daily snow depth on the ground. The Nipawin Station was located approximately $78 \mathrm{~km}$ southeast of the SOBS site, while the Thompson Station was located approximately $45 \mathrm{~km}$ southeast of the NOBS site.

\subsection{NASA Scatterometer (NSCAT)}

NSCAT flew onboard the Advanced Earth Observing Satellite (ADEOS), a mission of the National Space Development Agency (NASDA) of Japan. The platform was launched August 16, 1996, into a near-polar Sunsynchronous orbit and operated through June 30,1997, when the mission terminated because of power failure. The NSCAT instrument package consisted of a specialized microwave radar designed for measuring wind vectors over the global ocean [Naderi et al., 1991]. The scatterometer operated at a frequency of $13.995 \mathrm{GHz}$ ( $K_{u}$ band, corresponding to a $2.14 \mathrm{~cm}$ wavelength) and utilized an array of six antennas, providing both right- and left-looking 600-km-wide radar swaths, separated by a gap of approximately $330 \mathrm{~km}$. Incidence angle varied across each swath from approximately $15^{\circ}$ off nadir in the near range to $60^{\circ}$ in the far range. This configuration allowed coverage of $90 \%$ of the Earth's surface every 2 days. The overall backscatter measurement stability was about 0.3 dB [Tsai et al., 1999].

Although the primary focus of the NSCAT mission was monitoring ocean wind vectors, the high temporal fidelity of the data set provides opportunity for research into observation of landscape temporal dynamics. In our analysis, we utilize the NSCAT High-Resolution Merged Geophysical Data Product [Dunbar, 1996] to examine $25 \mathrm{~km}$ resolution cells over the BOREAS sites. NSCAT data were available for the BOREAS sites for 286 days, from September 15, 1996, to June 28, 1997. NSCAT overflights at the BOREAS sites occurred in the early morning (0515-0730) and late afternoon (1530-1750) at these BOREAS sites. Both morning (AM) and afternoon (PM) overflights were recorded on $270 \%$ of the days; only $\sim 5 \%$ of the days at the northern site and $\sim 14 \%$ of the days at the southern sites had neither AM nor PM NSCAT observations. Each resolution grid cell was normalized to $40^{\circ}$ incident angle through application of a function that describes the angular dependence of backscatter over the landscape [McDonald et al., 1998]. In general, dependence of $K_{u}$-band backscatter over the landscape may be described by a linear function [Kennett and $L i, 1989$ ]. However, the $25 \mathrm{~km}$ NSCAT data product employed in this study (version 1.1) exhibits a second-order response with incidence angle. This systematic pattern will be corrected in subsequent releases of the NSCAT data product. In this study we used version 1.1. data from NSCAT's aft vertically polarized antenna with a second-order correction. The data were then aggregated over the $50 \mathrm{~km}$ regions centered over the tower locations by averaging all backscatter pixels whose centers were within 25 $\mathrm{km}$ of the tower latitude/longitude. On days when there were two data values for a site (always separated by $100 \mathrm{~min}$, and so on consecutive orbits), we chose the earlier overpass because it was more likely to correspond to the time of the diurnal minimum (AM) or maximum (PM) temperature and thus to potential freeze or thaw signals.

\subsection{Land Cover Analysis}

Although there are only a few tree species in the boreal zone [e.g., Elliott-Fisk, 1988] and the central Canadian topography is quite flat, the boreal landscape is very heterogeneous. This heterogeneity is due in part to patchy disturbances (e.g., fire), discontinuous permafrost in the north, low topographic gradients and excess moisture generating local wetlands, and beaver activity [e.g., Larsen, 1980]. A great deal of effort in the BOREAS program has been and is being devoted to characterizing the land cover at various spatial resolutions and to understanding the implications of this varied landscape on biosphere-atmosphere interactions [e.g., Steyaert et al., 1997, Hall et al., 1997; Ranson et al., 1997]. Land cover classifications have been developed using optical remote sensing with both $\sim 1 \mathrm{~km}$ resolution AVHRR imagery [Steyaert et al., 1997]) and $\sim 30 \mathrm{~m}$ resolution Landsat thematic mapper (TM) imagery [Steyaert et al., 1997]). We summarize these results as percentage cover for the $50 \times 50 \mathrm{~km}$ NSCAT windows centered on the BOREAS tower sites in Table 1 . In general, land cover at SOA, and to the southwest of this, is predominantly deciduous and mixed conifer/deciduous (i.e., at least $\mathbf{2 0 - 8 0 \%}$ of each class) forest dominated by aspen (Populus tremuloides), jack pine (Pinus banksiana), and black spruce (Picea mariana) stands. The SOBS region

Table 1. Proportional Cover Within a 50 X $50 \mathrm{~km}$ Window Centered Over Tower-Flux Sites

\begin{tabular}{|c|c|c|c|c|c|c|}
\hline & \multicolumn{3}{|c|}{ Landsat $\mathrm{TM}^{\mathrm{s}}$} & \multicolumn{3}{|c|}{ AVHRR } \\
\hline & $\mathrm{SOA}^{6}$ & SOBS & NOBS & SOA & SOBS & NOBS \\
\hline Dry conifer & 0.01 & 0.01 & 0.02 & $<0.01$ & 0.02 & 0.09 \\
\hline Wet conifer & 0.20 & 0.37 & 0.08 & 0.02 & 0.60 & 0.50 \\
\hline Mixed deciduous-conifer & 0.23 & 0.13 & 0.06 & 0.61 & 0.25 & 0.30 \\
\hline Deciduous & 0.29 & 0.08 & 0.20 & - & - & - \\
\hline Regenerating conifer & 0.05 & 0.16 & 0.20 & - & - & - \\
\hline Regenerating deciduous & 0.11 & 0.05 & 0.16 & - & - & - \\
\hline Disturbed $^{d}$ & 0.01 & 0.02 & 0.02 & 0.35 & 0.07 & 0.08 \\
\hline Fen & 0.03 & 0.10 & 0.19 & $<0.01$ & $<0.01$ & $<0.01$ \\
\hline Fire blackened & $<0.01$ & $<0.01$ & $<0.01$ & - & - & - \\
\hline Grass & 0.01 & $<0.01$ & $<0.01$ & - & - & - \\
\hline Open water & 0.08 & 0.09 & 0.06 & 0.01 & 0.07 & 0.03 \\
\hline
\end{tabular}

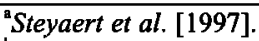

${ }^{\mathrm{t}} \mathrm{TM}$ data only cover $57 \%$ of this window; there are no data for areas in the S-SW; proportions are relative to the area of actual data.

Not a Landsat TM class in this analysis.

${ }^{d}$ This disturbed class included agricultural land in the AVHRR analysis. 


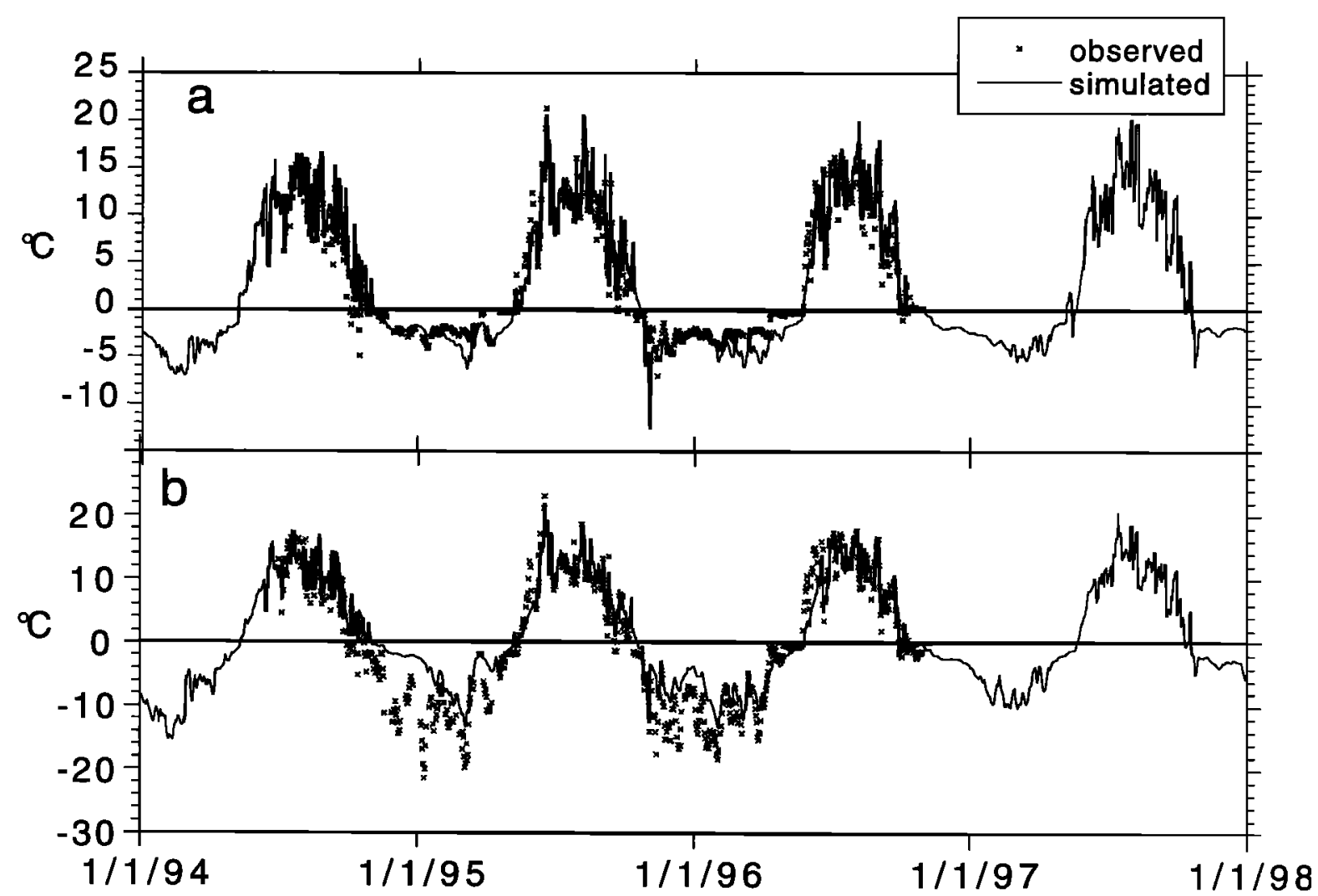

Figure 1. Observed [Goulden et al., 1997] and simulated [Frolking et al., 1996] $5 \mathrm{~cm}$ soil temperature for the BOREAS NOBS stand (a) with a relatively open canopy and Sphagnum moss ground cover and (b) with a relatively closed canopy and feathermoss ground cover. In both cases the surface organic horizon was greater than $15 \mathrm{~cm}$ thick, so the data and simulations represent conditions within the organic layer under the live moss.

(about $80 \mathrm{~km}$ to the east of SOA) is much more dominated by the wet conifer class (i.e., muskeg or black spruce peatlands). Agricultural development, consisting of both row crops and pasture, is also present in the southern portions of the SOA and SOBS windows but is absent within the NOBS study region; this land cover is in the "disturbed" class in the AVHRR data in Table 1. These areas are represented in the AVHRR land cover classification but are not fully represented in the TM classification due to incomplete TM coverage within the SOA window (see Table 1). Many small-scale landscape features (e.g., fens) cannot be resolved at $1 \mathrm{~km}$ and thus are probably underrepresented in the AVHRR analysis and perhaps also in the TM analysis. To the south and southeast of the NOBS tower, and within the NSCAT pixel and land cover analysis (Table 1), are large fire scars. These areas are regrowing and were identified as regenerating conifer and regenerating deciduous forests from the TM classification map. Similar though less extensive fire-scarred areas within the SOBS window (part of the 1977 Fish Lake burn) are dominated by small ( $<5 \mathrm{~cm}$ diameter at breast height) jack pine, black spruce, and aspen regrowth [Hall et al., 1997; Saatchi and Rignot, 1997].

\subsection{Soil Temperature Simulations}

Soil temperatures were not reported in the BOREAS database for the spring of 1997 , so we simulated soil temperatures using the model of Frolking et al. [1996]. Simulations were run for each of the BOREAS tower sites, driven by daily meteorological observations at Thompson and Nipawin. For the NOBS site, two ground cover classes were simulated, with black spruce underlain by either feathermoss or sphagnum moss. Time of thaw at $5 \mathrm{~cm}$ was in good agreement with observations at NOBS [Goulden et al., 1997] in 1995 and 1996 for both ground cover types (Figure 1). For all three sites, the surface organic horizons were $>5 \mathrm{~cm}$ thick, so $5 \mathrm{~cm}$ soil depth was above the mineral soil.

\section{Analysis and Results}

\subsection{AM and PM Differences}

At each location, AM and PM NSCAT backscatter signals had similar seasonalities, though the PM overflights often had greater variability from one day to the next (Figure 2). AM overflights occurred in the early morning and should be roughly coincident with the diumal minimum temperature and thus the maximum degree of frost, while PM overflights were in late afternoon and should be roughly coincident with the diurnal maximum temperature and thus the minimum degree of frost. PM backscatter values were generally lower than AM values for the two coniferous sites during the spring and early summer of 1997 and were more dynamic than the AM overflights during the period of snowmelt and thaw. 


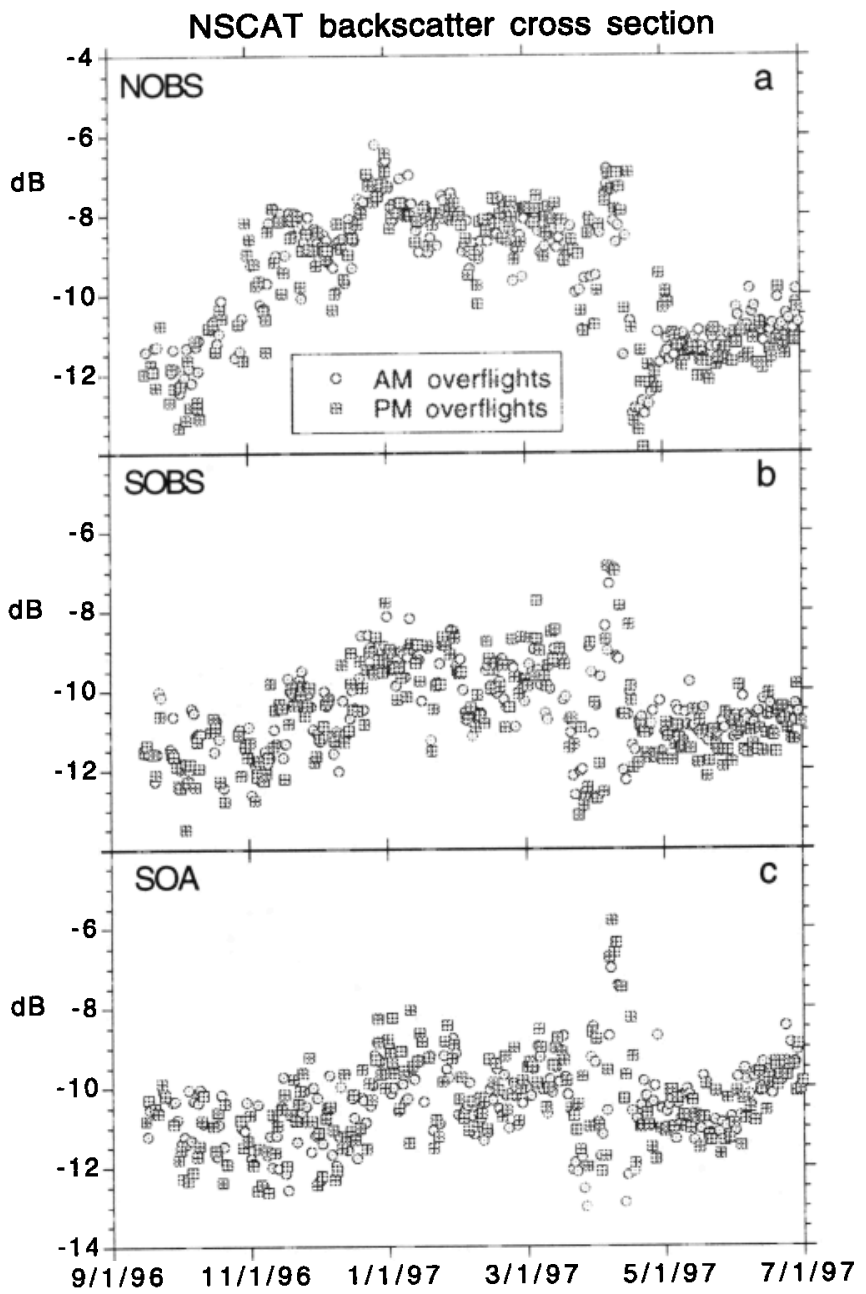

Figure 2. NASA scatterometer (NSCAT) microwave backscatter for morning (AM) and afternoon (PM) overflights of the (a) NOBS, (b) SOBS, and (c) SOA BOREAS tower sites. NSCAT was operational from September 15, 1996 to June 28, 1997.

\subsection{NSCAT Backscatter and Environmental Variables}

To generate a smoothed AM or PM signal, we calculated for each day the average of that day's and the previous four days' backscatter values (in a few cases with missing values these averages used only one or two data points). This smoothing was done for each site on AM and PM data separately and also on the combined AM and PM data sets.

Major fluctuations in the NSCAT backscatter $\left(\sigma^{0}\right)$ time series for the NOBS site showed a strong correlation with environmental variables (Figure $3 \mathrm{a}$ ). The first significant rise in $\sigma^{0}(2 \mathrm{~dB})$ occurred with the arrival of the first snow. $A$ second, stronger rise in $\sigma^{0}(3 \mathrm{~dB})$ occurred after a melt with the reestablishment of snow cover and a drop in temperature around November 1, 1996. There was then a brief drop in $\sigma^{0}$ with a warmer period and perhaps some melting of the snow. The third rise in $\sigma^{0}(2.5 \mathrm{~dB})$ occurred several days after the third heavy snowfall when the air temperatures got quite cold $\left(T_{\max }<-30^{\circ} \mathrm{C}\right) ; \sigma^{0}$ dropped $2 \mathrm{~dB}$ in early February 1997 when $T_{\max }$ rose above $0^{\circ} \mathrm{C}$, then rose again when the weather cooled. Several days with $T_{\max }>0^{\circ} \mathrm{C}$ in late March 1997 caused $\sigma^{0}$ to drop below $-10 \mathrm{~dB}$; then a week of cold weather sent $\sigma^{0}$ back

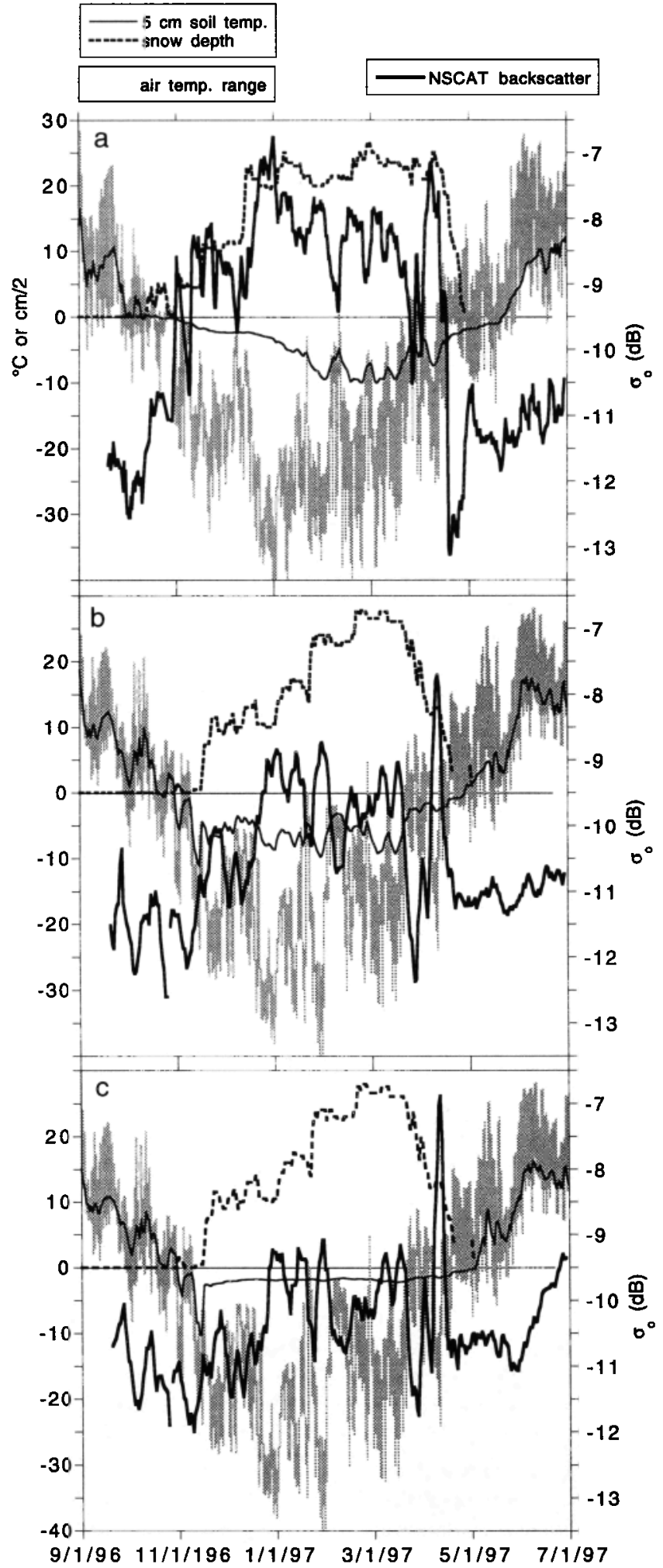

Figure 3. NSCAT backscatter (thick black line), observed diurnal air temperature range (shaded bars) and snow depth (dashed line), and simulated $5 \mathrm{~cm}$ soil temperature (thin black line) for the (a) NOBS, (b) SOBS, and (c) SOA BOREAS tower sites for September 15, 1996 to June 28, 1997. The diurnal air temperature range is plotted as a gray vertical bar extending each day from the minimum to the maximum air temperature. Soil temperature simulations were done with the model of Frolking et al. [1996]. 
Table 2. Statistics of NSCAT Backscatter $\left(\sigma^{0}\right)$ and Smoothed First-Differences

\begin{tabular}{lcccccc}
\hline Site & $\boldsymbol{n}$ & $\begin{array}{c}\text { Mean }^{2} \\
(\mathrm{~dB})\end{array}$ & $\boldsymbol{S}^{b}$ & $\begin{array}{c}\text { Number of Days } \\
\text { Outside } 2 S\end{array}$ & $\begin{array}{c}\text { June Mean } \boldsymbol{\sigma}^{0} \\
(\mathrm{~dB})\end{array}$ & $\begin{array}{c}\text { Feb. Mean } \sigma^{0} \\
(\mathrm{~dB})\end{array}$ \\
\hline NOBS PM & 277 & 0.003 & 0.297 & 16 & -11.283 & -8.377 \\
NOBS AM & 276 & 0.010 & 0.223 & 14 & -10.727 & -8.343 \\
SOBS PM & 278 & -0.004 & 0.308 & 16 & -11.015 & -9.908 \\
SOBS AM & 275 & 0.000 & 0.262 & 15 & -10.691 & -9.978 \\
SOA PM & 279 & -0.001 & 0.316 & 16 & -10.108 & -10.211 \\
SOA AM & 275 & 0.006 & 0.332 & 11 & -9.855 & -10.450 \\
\hline
\end{tabular}

${ }^{2}$ Mean of smoothed first-differences of NSCAT backscatter.

${ }^{\mathrm{b}} S$, standard deviation of smoothed first-differences.

up to $-7 \mathrm{~dB} . \sigma^{0}$ plunged to $-13 \mathrm{~dB}$ as the snowpack melted, and $\sigma^{0}$ rebounded to around $-11 \mathrm{~dB}$ when the snowpack was gone. Note that the soil did not thaw at $5 \mathrm{~cm}$ depth until several weeks after the backscatter had returned to its thawed range (Figure 3a). There was a strong seasonality to $\sigma^{0}$ at the NOBS site, which correlated with air temperature $\left(r^{2} \sim 0.6\right)$ and snow depth $\left(r^{2} \sim 0.4\right)$. NSCAT backscatter values at the two southern sites (Figures 3b, 3c) also showed fluctuations coincident with changes in snowpack and large temperature fluctuations; the deciduous site (SOA) exhibited the least amount of variation with seasonal transitions although the dynamic range in the backscatter temporal response to the 1997 springtime thaw was similar for all three sites.

\subsection{First Differences of the NSCAT Signal}

We calculated the first difference of the smoothed NSCAT $\mathrm{AM}$ and $\mathrm{PM}$ signals for each site (first difference is equal to $\sigma^{0}$ of day $i$ minus $\sigma^{0}$ of day $i-1$ ). These first differences were normally distributed about a near-zero mean (Table 2), and we calculated the standard deviation of the first differences. To select those periods when the backscatter was most dynamic, we identified those first differences which were more than 2 standard deviations from the mean (Figure 4). The numbers of days with first differences outside 2 standard deviations ranged from 11 for SOA AM overflights to 16 for all PM overflights (Table 2).

\section{Discussion and Conclusions}

\subsection{Detecting Freezing and Thawing}

One algorithm developed for detecting freezing and thawing from ERS-1 SAR microwave backscatter relied on a 3 $\mathrm{dB}$ change in backscatter from the thawed values observed in midsummer (Rignot and Way, 1994]. Since there are no NSCAT data from midsummer (July) due to platform failure, we used the June mean $\sigma^{0}$ for morning and evening overflights at each sight to represent the signal for the thawed state (Table 2). We then computed the difference from this mean for the 5day smoothed $\sigma^{0}$ for each overflight time. Using a 3 dB threshold does not account for variation in backscatter sensitivity to freeze/thaw transitions driven by gross landscape features (e.g., topography, vegetation cover). This technique would predict only intermittent freezing at the northern site and no real freezing at the southern sites, despite air temperatures as low as $-40^{\circ} \mathrm{C}$.

Boehnke and Wismann [1997] proposed the mean of summer and winter ERS-1 scatterometer backscatter as a freeze/thaw threshold. They observed a 3-4 dB increase in backscatter from test sites in Siberia during spring thaw, which they attribute to snowmelt, but without any ground observations. We observe different temporal trends in the
NSCAT data sets, with spring thaw resulting in decreasing backscatter. The ERS-1 scatterometer has a frequency of 5.3 $\mathrm{GHz}$ (wavelength $=5.7 \mathrm{~cm}$ ), 2.66 times longer than NSCAT. The difference in NSCAT and ERS-1 temporal responses to changes in landscape freeze/thaw state arises in part from variations in relative contribution to the composite backscatter of surface and volume-scattering effects. Boehnke and Wismann [1997] observed an increase in the volume scattering component of the composite ERS backscatter from sparse vegetation cover after thaw. Examination of NSCAT winter and spring data indicate no such variation over forested areas. In general, the energy from the higher-frequency scatterometer penetrates less into the vegetation medium, yielding less volume scattering. Applying the algorithm of Boehnke and Wismann [1997] to the NSCAT data, using the June mean to represent the thawed state and the February mean for the frozen state (Table 2), the NOBS site would freeze on November 1, thaw briefly and refreeze a week later, thaw briefly on March 27, and thaw for the summer on April 18 (Figure 5a). The SOBS site would freeze briefly on November 22, freeze again on December 19, thaw briefly on February 6 , thaw on March 22, freeze briefly on April 6, and thaw for the summer on April 18 (Figure 5b). For the SOA site, AM and PM overflights the June (thawed) mean $\sigma^{0}$ values were higher than the February (frozen) mean $\sigma^{0}$ values (Table 2). This freeze/thaw algorithm would have the site freezing and thawing throughout the winter (Figure 5c) and then freezing up on June 11 until the end of the instrument record (June 30). This final rise in backscatter (interpreted by this algorithm as a freeze-up) was more likely due to a rise in deciduous vegetation leaf area than to freezing (see section 4.3).

Evaluating "anomalous" first-differences of the smoothed $\sigma^{0}$ signal (more than 2 standard deviations from the mean; see Figure 4) may also be able to identify changes in the landscape freeze/thaw state. Most days with anomalous first differences were coincident with either fresh snowfall or snowmelt (Tables 3 and 4). The late September anomalies at the SOBS site may be due to missing data (September 25-27) and thus less smoothing (though a similar data gap at this site 15 days later did not generate first difference anomalies) or to changes in leaf water content as the canopy senesced. At the time of snowmelt, all sites show a number of large, consecutive first-difference anomalies, corresponding to both warmer air temperatures $\left(T_{\text {air }}>0^{\circ} \mathrm{C}\right)$, decreasing snow depths, a wetter snowpack, and new snowfall. Not every snowstorm generated a first-difference anomaly signal. This may be due to spatial heterogeneity in precipitation, i.e., differences in precipitation between a point measurement from a single station and precipitation characteristics within the 50 × $50 \mathrm{~km}$ NSCAT window. Another reason might be that snowpack characteristics do not necessarily change with each new storm and do not change only with a snowstorm. However, without 


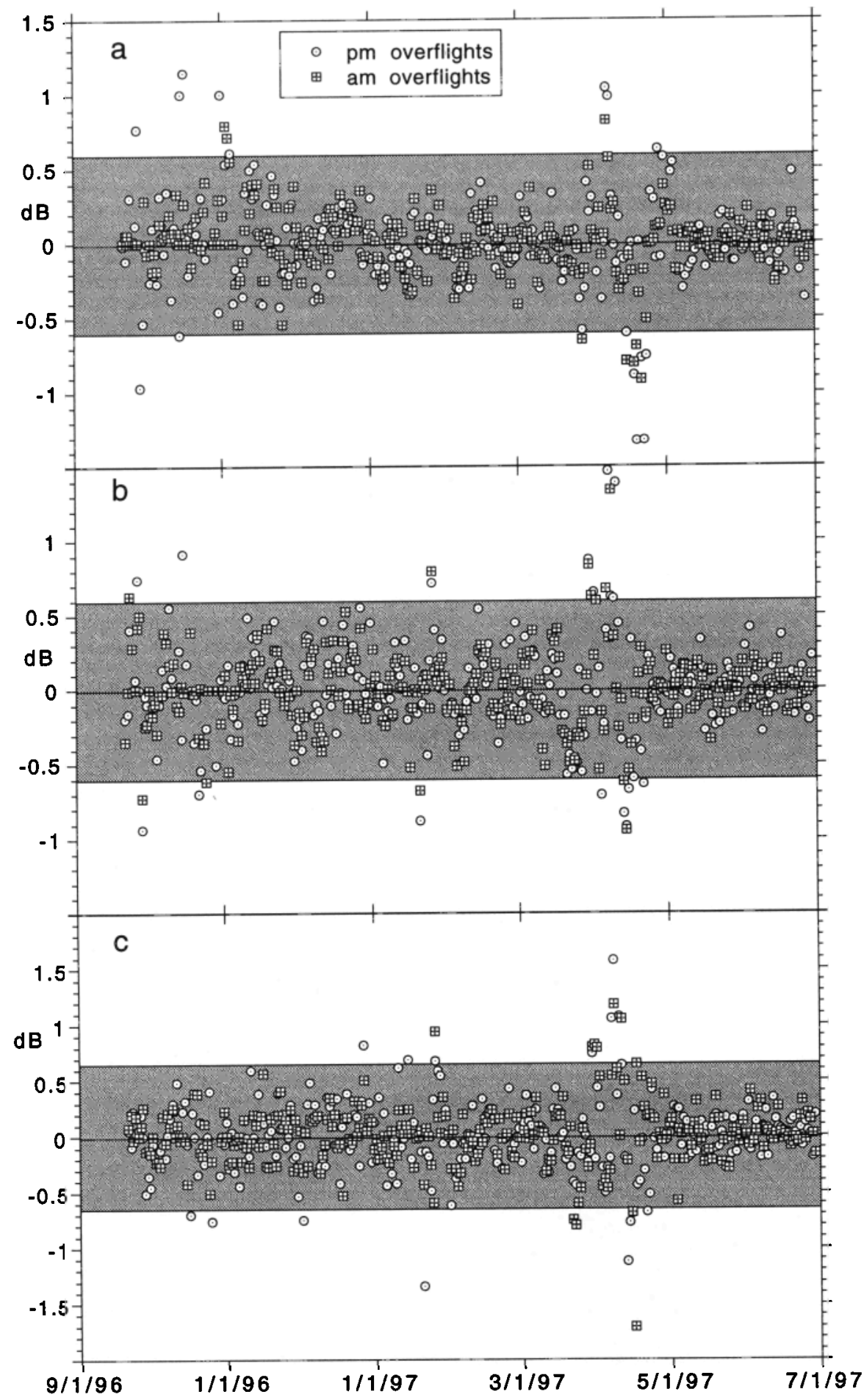

Figure 4. First differences of the 5-day smoothed AM and PM NSCAT backscatter for the (a) NOBS, (b) SOBS, and (c) SOA BOREAS tower sites for September 15, 1996 to June 28, 1997 (see text for details of calculations). The shaded regions in each panel represent 2 standard deviations around the mean first differences for each site (see Table 2). "Anomalous" first differences, greater than 2 standard deviations from the mean, occur in the fall and spring at all three sites, and during the winter at SOBS and SOA. See Tables 3 and 4 for an evaluation of the anomalous dates.

better instrumentation (e.g., more stations, snow density and crystal size measurements) this cannot be documented. These anomalies in the first difference of the NSCAT smoothed backscatter signal might be useful as a detection algorithm for changes in snowpack properties and canopy freeze/thaw state but not to soil freeze/thaw.
The strongest signal in the 9-month NSCAT backscatter record was the $\sim 3-6 \mathrm{~dB}$ decrease that occurred with snowpack ripening and melting in the spring. Soil thaw generally lags snowmelt by days (depths of a few centimeters) to weeks (depths of tens of centimeters). Tree bole temperatures measured in 1994 at the SOBS site [Way et al., 1997] were 


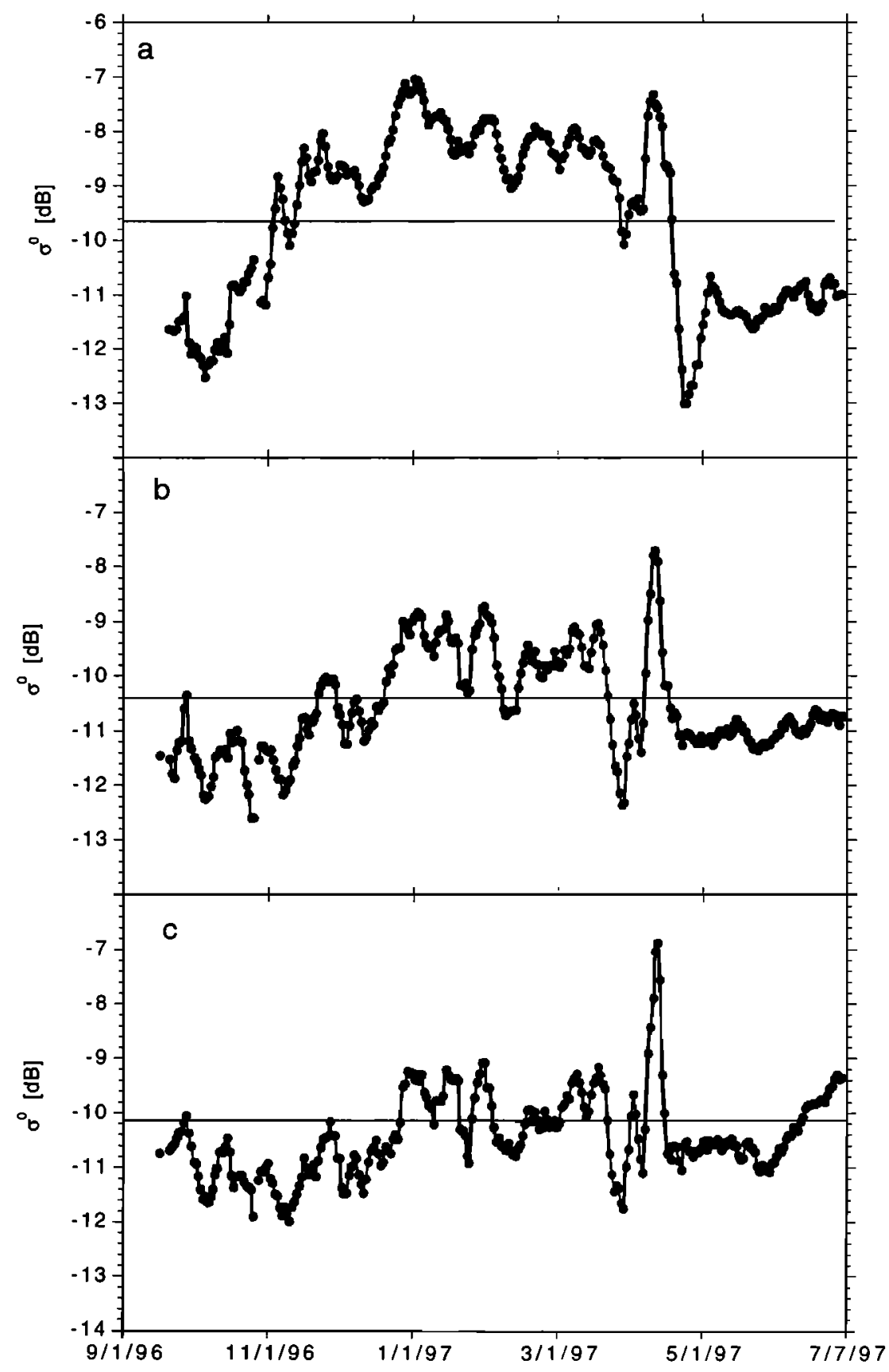

Figure 5. Five-day smoothed NSCAT backscatter for the NOBS, SOBS, and SOA BOREAS tower sites for September 15, 1996 to June 28, 1997. This smoothing combined AM and PM overflight data. The horizontal lines represent the mean of February (frozen) and June (thawed) mean NSCAT backscatter for each site and thus a proposed freeze/thaw threshold [Boehnke and Wismann, 1997].

very similar to observed air temperatures, so any melting of the snowpack would be coincident with a thawing of the tree canopy, which would also contribute to a change in the NSCAT signal. In the north this was a single event which began on April 11, 1997; in the south the melt began on March 15, 1997, was interrupted by a period of refreezing beginning on April 2, 1997, and a final melting beginning on April 11, 1997. This suggests that NSCAT detected northsouth variations spring thaw, a key ecosystem growing season signal.
4.2. Snowpack Dynamics and Comparison to ERS Scatterometer

NSCAT $\sigma^{0}$ values appear to be much more variable throughout the frozen season than ERS-1 $\sigma^{0}$ values [Boehnke and Wismann, 1997]. Since the vegetation canopy structure probably changed very little over the 9 months of NSCAT operation (except for deciduous vegetation leaf development discussed below), the variability in the $\sigma^{0}$ signal is probably 
Table 3. NOBS Site Anomalous Backscatter and Weather

\begin{tabular}{lccl}
\hline \multicolumn{5}{c}{ PM } & AM & Weather at Thompson, Manitoba \\
\hline 27-Sep-96 & $(++)^{\mathrm{a}}$ & & $T_{\min }<0^{\circ} \mathrm{C}$ (not first of ycar) \\
28-Sep-96 & $(--)$ & & light snow \\
14-Oct-96 & $(--)$ & & new snow $\left(T-0^{\circ} \mathrm{C}\right)$ \\
15-Oct-96 & $(++)$ & & new snow $\left(T-0^{\circ} \mathrm{C}\right)$ \\
$16-$-Oct-96 & $(++)$ & & rain on snow $\left(T-0^{\circ} \mathrm{C}\right)$ \\
31-Oct-96 & + & & new snow \\
2-Nov-96 & & $(++)$ & ??? \\
3-Nov-96 & & $(++)$ & maybe new snow \\
4-Nov-96 & + & $(++)$ & maybe new snow \\
7-Nov-96 & & - & new snow \\
25-Nov-96 & & - & ncw snow; extreme cold \\
28-Mar-97 & & - & ncw snow \\
31-Mar-97 & & + & snowmelt \\
6-Apr-97 & $(++)$ & $(++)$ & new snow \\
7-Apr-97 & $(++)$ & $(++)$ & ncw snow \\
14-Apr-97 & - & - & snowmelt \\
17-Apr-97 & $(--)$ & $(--)$ & snowmelt and $T_{\operatorname{mar}}>0^{\circ} \mathrm{C}, T_{\min }<0^{\circ} \mathrm{C}$ \\
18-Apr-97 & $(--)$ & $(--)$ & snowmelt and $T_{\max }>0^{\circ} \mathrm{C}, T_{\min }<0^{\circ} \mathrm{C}$ \\
20-Apr-97 & $(--)$ & - & snowmelt and $T_{\max }>0^{\circ} \mathrm{C}, T_{\min }<0^{\circ} \mathrm{C}$ \\
21-Apr-97 & $(--)$ & & snowmelt and $T_{\operatorname{mux}}>0^{\circ} \mathrm{C}, T_{\min }<0^{\circ} \mathrm{C}$ \\
22-Apr-97 & $(--)$ & - & snowmelt and $T_{\max }>0^{\circ} \mathrm{C}, T_{\min }<0^{\circ} \mathrm{C}$ \\
27-Apr-97 & + & & snowmelt and $T_{\max }>0^{\circ} \mathrm{C}, T_{\min }<0^{\circ} \mathrm{C}$ \\
\hline
\end{tabular}

Read 27-Sep-96 as September 27, 1996. Plus sign, for positive anomaly, minus, for negative anomaly; blank or not listed, if not anomalous (see Figure 3).

${ }^{\circ}$ Consecutive days with anomalies have double symbols and are in parentheses.

due to changes in snow cover (including snow caught in the tree canopy), changes in snow properties (particularly near the snow surface), and changes in relative amounts of liquid and frozen water of the vegetation canopies. NSCAT $\sigma^{0}$ values are not likely to be strongly influenced by the state of the soil, except for areas with scant or no vegetation (e.g., recent disturbance sites). The longer wavelength ERS scatterometer will penetrate deeper into the scattering volume (canopy, snowpack, and soil) and be more influenced by volume scattering than surface scattering, which may account for the smoother winter signal reported by Boehnke and Wismann, [1997].

Bulk snowpack densities were measured in the BOREAS study areas in the winters of 1993-1994, 1994-1995, and 1995-1996; bulk density rose slowly through the winter from $-0.1 \mathrm{~g} / \mathrm{cm}^{3}$ to $-0.18 \mathrm{~g} / \mathrm{cm}^{3}$ and then at the onset of melting (around April 1 each year) rose rapidly to $\sim 0.3 \mathrm{~g} / \mathrm{cm}^{3}$ (B. Goodison et al., unpublished BOREAS data, 1998) (hereinafter referred to as G98). The only snowpack data available to this study for the winter of 1996-7 were the daily observed snow depths at the weather stations in Thompson and Nipawin. While snow depth data give crude information (arrival of snow and timing of major snowmelts in particular), they do not provide any details on the changing characteristics of the snow cover which can influence the microwave backscatter at the NSCAT frequency. Dry snow will have a very small absorption of microwaves, while liquid water in wet snow is strongly absorbing [Kunzi et al., 1982].
Inhomogeneities in the snow structure can have dimensions comparable to the NSCAT wavelength $(-2 \mathrm{~cm})$ and thus can cause significant volume scattering [Shi et al., 1993; Kunzi et al., 1982]. However, snowpack structure can vary significantly throughout a winter [e.g., Colbeck, 1982], and these changes can influence how microwaves interact with the snowpack [Wankiewicz, 1993]. In addition, the characteristics of the snowpack can change dramatically across the landscape; digging detailed snow pits in a transect across northern Alaska, Hall et al. [1991] found seven different classes of snow (new snow, melt-freeze layer, small rounded snow grains, large rounded snow grains, wind crust, depth hoar crystals, and partially decomposed precipitation particles) within $10 \mathrm{~cm}$ of the snowpack surface. NSCAT's short wavelength will make it sensitive to this level of detail in the snowpack properties. In addition, the NSCAT signal will be very sensitive to the amount and characteristics of snow held by the vegetation canopy.

During the snowmelt period the boreal landscape will transform from snow-covered first to a mosaic of wet (melting) snow and snow-free patches with a very wet surface layer (often organic material) and frozen soil deeper down, and finally to a snow-free, generally wet surface with thawing soils at depth. During this period the vegetation will also thaw, yielding associated increases in vegetation dielectric constant, simultaneous with changes in the underlying snow and soil. Coarse spatial resolution scatterometers (both the ERS-1 scatterometer and the NSCAT) will detect these transformations as a major change in backscatter at the time of thaw, and they will be more sensitive to the earlier stages of this transition than to the final thawing at depth. The shorter the radar wavelength, the less it will penetrate into the scattering surface/volume (vegetation, snow, and soil), and the more sensitive it will be to the initial stages of thaw. The relative contributions of vegetation, snowpack and soil to the backscatter will depend both on the radar wavelength and on the vegetation canopy density and degree of disturbance (unvegetated land) across the landscape.

\subsection{Spring Leaf Area Development at SOA}

The NSCAT backscatter signal at the SOA site rises steadily during June 1997, while the SOBS and NOBS backscatter signals do not (Figure 2). This rise in backscatter was coincident with the development of leaf area in the SOA canopy. We can compare 1994 leaf area index (LAI) development [Blanken et al., 1997] with 1997 NSCAT backscatter for May and June (Figure 6a). Note that spring came somewhat earlier in 1994 than in 1997, as shown in the accumulating positive degree days observed at Nipawin, Saskatchewan for those years (Figure 6b). The radar signal will be most sensitive to changes in scatterers whose sizes are greater than or of the order of the radar wavelength $(2.14 \mathrm{~cm}$ for NSCAT). Thus the size and number of leaves as well as their water content will affect backscatter. It is likely that the NSCAT backscatter was rising for this site because of the growing leaf biomass and total water content of the canopy. Unfortunately, the NSCAT data record ended at the end of June, as leaf area development was nearing completion, so a further test of this will require a longer data set, which should become available with the launch of a follow-on instrument, QuikScat, scheduled for April 1999. 
Table 4. Southern Sites Anomalous Backscatter and Local Weather

\begin{tabular}{|c|c|c|c|c|c|}
\hline & SOBS PM & SOBS AM & SOA PM & SOA AM & Weather at Nipawin, Sask. \\
\hline 23-Sep-96 & & + & & & $? ? ?$ \\
\hline 26-Sep-96 & + & & & & $? ? ?$ \\
\hline 28-Sep-96 & - & - & & & $? ? ?$ \\
\hline $15-$ Oct-96 & + & & & & $T_{\min }<0^{\circ} \mathrm{C}$ but not first of year \\
\hline $16-O c t-96$ & & & - & & $? ? ?$ \\
\hline 21-Oct-96 & - & & & & $T_{m+n}<0^{\circ} \mathrm{C}$ \\
\hline 24-Oct-96 & & - & & & $T_{\max }<0^{\circ} \mathrm{C}$ (first of year) \\
\hline $25-$ Oct-96 & & & - & & new snow \\
\hline 2-Nov-96 & & - & & & new snow (also days $304-305$ ) \\
\hline 1-Dec-96 & & & - & & $? ? ?$ \\
\hline 26-Dec-96 & & & + & & some snowmelt \\
\hline 13-Jan-97 & & & + & & some snowmelt \\
\hline 19-Jan-97 & - & - & - & & extreme cold (6th day of cold) \\
\hline 24-Jan-97 & + & + & + & + & $? ? ?$ \\
\hline 21-Mar-97 & & & & $(--)$ & new snow \\
\hline 22-Mar-97 & & & & $(-)$ & new snow \\
\hline 29-Mar-97 & + & $(++)$ & + & $(++)$ & $? ?$ \\
\hline 30-Mar-97 & & $(++)$ & & $(++)$ & $? ?$ \\
\hline 31-Mar-97 & + & & & $(++)$ & new snow \\
\hline 1-Apr-97 & & $(++)$ & & & new snow \\
\hline 2-Apr-97 & & $(--)$ & & & $? ? ?$ \\
\hline 3-Apr-97 & - & & & & new snow \\
\hline 5-Apr-97 & & + & & & $T_{\max }>0^{\circ} \mathrm{C}$ (not first of year) \\
\hline 6-Apr-97 & $(++)$ & & $(++)$ & & $T_{\max }>0^{\circ} \mathrm{C}$ and new snow \\
\hline 7-Apr-97 & $(++)$ & + & $(++)$ & + & $T_{\max }>0^{\circ} \mathrm{C}$ \\
\hline 9-Apr-97 & + & & $(++)$ & & snowmelt \\
\hline 10-Apr-97 & & & $(++)$ & + & snowmelt \\
\hline 12-Apr-97 & $(--)$ & $(--)$ & $(--)$ & & probable rain \\
\hline 13-Apr-97 & $(--)$ & $(--)$ & $(--)$ & $(--)$ & snowmelt \\
\hline 14-Apr-97 & $(--)$ & $(--)$ & - & $(--)$ & snowmelt \\
\hline 15-Apr-97 & & & & $(--)$ & snowmelt \\
\hline 20-Apr-97 & - & & - & & new snow \\
\hline
\end{tabular}

\subsection{Difference Between Northern and Southern Sites}

The predominant difference between the NSCAT backscatter signal at the northern site and the two southern sites was the stronger seasonality of the signal in the north (see Figure 5). This difference between the northern and the southern sites could be due to differences in the quantity or quality of the snowpack and/or to differences in the vegetation canopy. Measured snow depths were similar at both the northern and the southern weather stations (see Figure 3), as were snowpack densities in earlier years (G98). The southern region averaged about $1^{\circ} \mathrm{C}$ warmer than the northern region during the period of snow cover and had more periods of near $0^{\circ} \mathrm{C}$ temperatures than the north, and so might have a different character to its snowpack. However, it was still quite cold at these southern sites (mean January 1997 temperature was $-21.7^{\circ} \mathrm{C}$ ) and certainly frozen for most of the winter.

On the basis of optical remote sensing land cover classifications [Steyaert et al., 1997] the northern BOREAS area had more fire scars and regenerating vegetation, more rock outcrops and bare ground, generally lower canopy density for the dominant land cover class (wet conifer), and less mixed canopy forests with $>50 \%$ deciduous vegetation than the southern BOREAS area. Chen et al., [1997] report leaf area index values for "disturbed" black spruce sites near NOBS and SOBS at 0.33-1.31, while mature black spruce stand LAI values generally range from 1.5 to 3.0. Ranson et al. [1997] reported for jack pine stands in the BOREAS southern study area that trees in regenerating sites (5-10 years since disturbance) had heights of 1-3 m, while mature jack pine forests (70-90 years since disturbance) had tree heights of 13$18 \mathrm{~m}$ Analysis with the shuttle imaging radar (SIR-C) showed a tenfold increase in aboveground biomass between regenerating and mature stands [Ranson et al., 1997]. With more disturbed area and a generally lower canopy density in the north, the ground snow cover would have more influence on the NSCAT backscatter. However, the southern study area had more open water (and larger water bodies) and more agricultural land (generally bare ground in winter). The snowpack in these larger open regions might be different from forest snowpacks, due to greater exposure to wind and direct sunlight. Within the $50 \times 50 \mathrm{~km}$ cells at the three tower sites selected for this study, however, the land cover differences between south and north (see Table 1) are not so great as the general differences between north and south reported by Steyaert et al. [1997]. A further analysis of north-south gradients in the NSCAT signal across a broader region of the boreal ecozone is needed to evaluate this. 


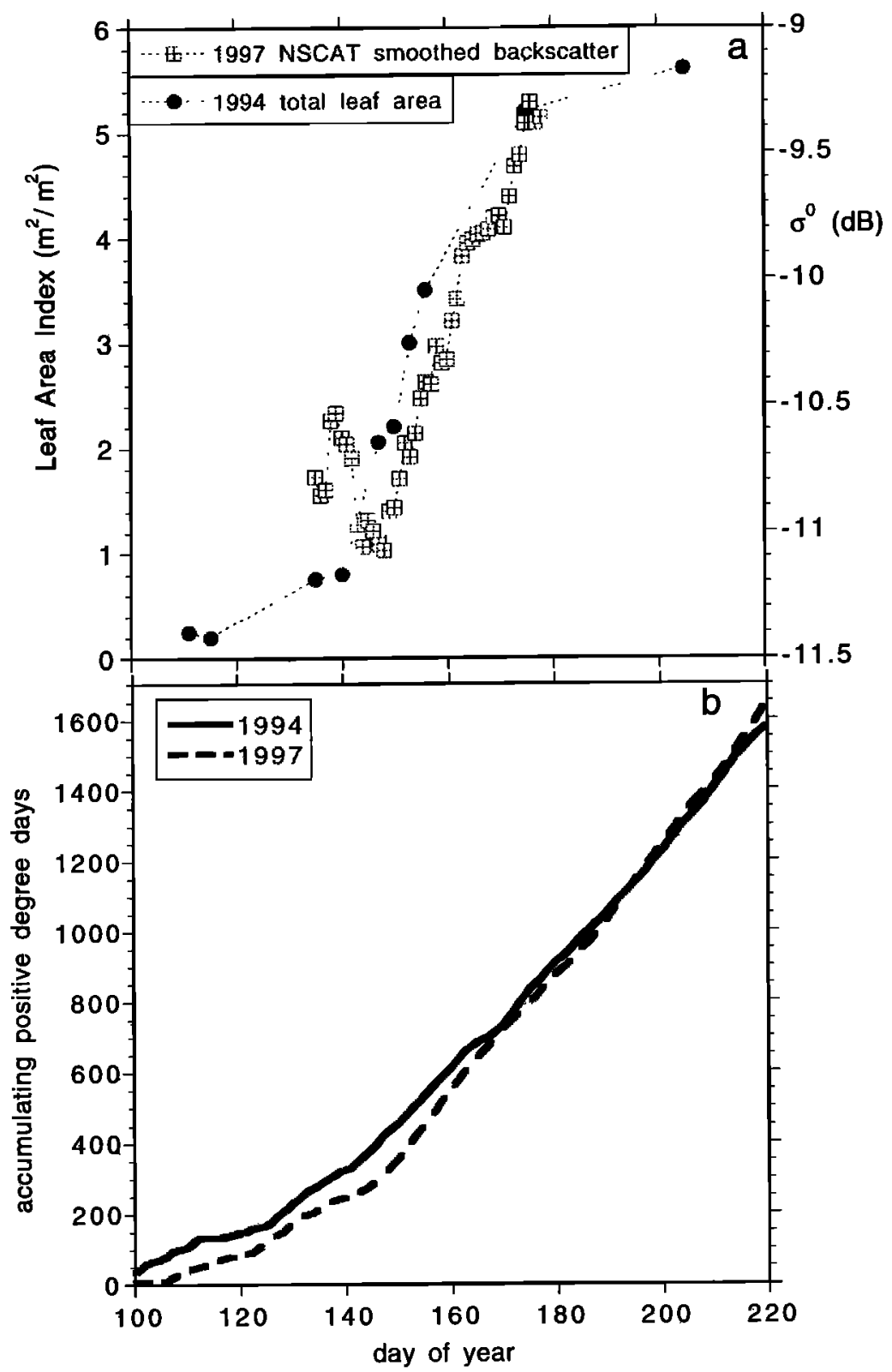

Figure 6. (a) Five-day smoothed NSCAT backscatter for the SOA BOREAS tower site for May 15 through June 28, 1997 (hatched squares), and observed total leaf area index development (circles) at the SOA BOREAS tower site in 1994 [Blanken et al., 1997]. The rise in NSCAT backscatter over this interval appears to be coincident with deciduous vegetation leaf development. (b) Accumulating positive degree days at the SOA BOREAS tower site in 1994 (solid line) and 1997 (dashed line); note that warming in 1994 occurred earlier than in 1997, so leaf development in 1994 probably also occurred earlier than in 1997.

\subsection{Ecosystem Growing Season Boundaries}

The pattern of net ecosystem productivity in the boreal zone is one of a rapid onset of carbon uptake (immediately after snowmelt and soil thaw in evergreen systems and upon leafout in deciduous systems), highest rates of uptake during the early summer (when light levels are high, water is generally abundant, and soils are still cool), declining uptake in late summer, significant loss (respiration) during late autumn and early winter until the soils cool and freeze, and low rates of loss during the bulk of the winter [e.g., Goulden et al., 1997; Kimball et al., 1997; Black et al., 1996; Frolking et al.,
1996]. NSCAT's strong spring thaw signal coincided with the end of the ecosystem's steady winter respiration period (Figure 7). The NSCAT thaw signal occurred at the beginning of snowmelt; net carbon uptake by the forest ecosystem (positive net ecosystem exchange (NEE) of $\mathrm{CO}_{2}$ in Figure 7) began when the snow had completed melting about 30 days later (see Figure 3a). Because liquid water is abundant across the landscape at snowmelt, the high-frequency NSCAT signal will not penetrate into the soil and will be unable to monitor its freeze/thaw state. The end of the growing season occurred in late September 1996 in both model simulations, when diurnal minimum air temperatures were consistently below 


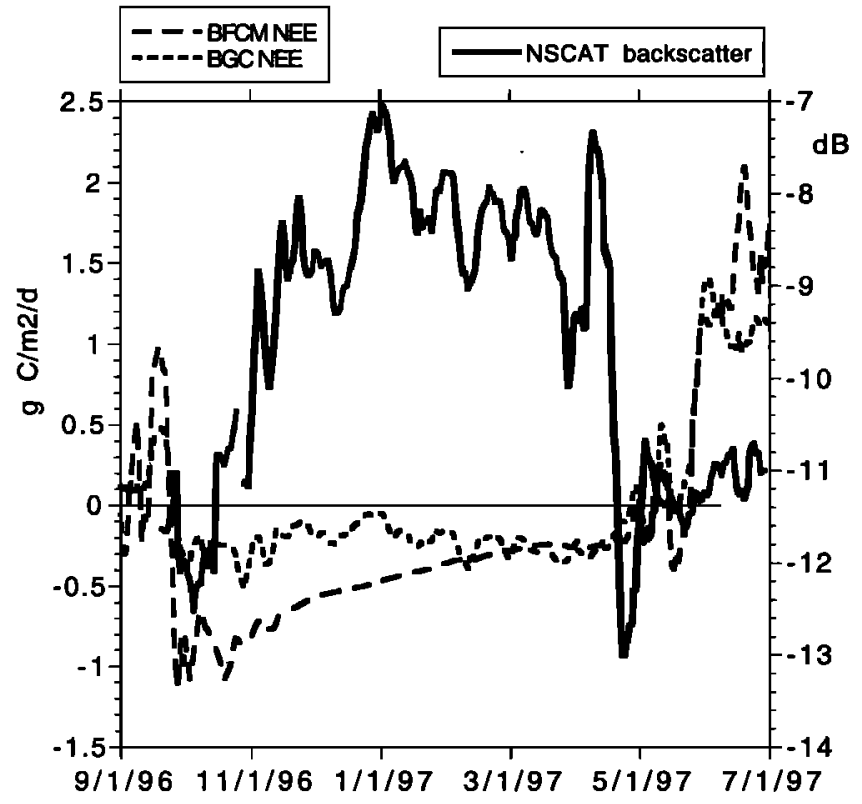

Figure 7. Five-day smoothed NSCAT backscatter for the NOBS BOREAS tower site, and five-day smoothed net ecosystem exchange (NEE) of carbon dioxide for this site as simulated by the Boreal Forest Carbon Model (BFCM [Frolking et al., 1996]) and BIOME-BGC [Kimball et al., 1997]. The sign convention used is for positive NEE to mean net ecosystem uptake of $\mathrm{CO}_{2}$ from the atmosphere.

$0^{\circ} \mathrm{C}$. The NSCAT backscatter dropped by about $1 \mathrm{~dB}$ at this time (Figure 7), but this was very near the beginning of the record. Shifts in NSCAT backscatter during the winter did not correspond to major shifts in NEE (Figure 7) as the soils were cold and the ground snow covered all winter long.

\subsection{Conclusions}

NSCAT operated for only about 9.5 months, which was not long enough to thoroughly evaluate its potential as an Earth system monitoring instrument. A follow-on instrument, QuikScat, with similar characteristics to NSCAT, is scheduled for launch in April 1999. As QuikScat data become available, a more complete analysis of the annual cycle and of interannual variability in this cycle will be possible. The NSCAT analysis reported here indicates that $K_{u}$-band active microwave scatterometers can bound the growing season in the boreal zone by signaling the arrival of the snowpack and the onset of snowmelt and surface thaw. A direct correlative analysis with vegetation temperature was not possible as in situ measurements were not available during the NSCAT lifetime. However, the arrival and departure of snow is roughly coincident with ecosystem freezing and thawing, though soil freezing can lag snowfall if snowfall is early and heavy, and lead it otherwise, and soil thawing in spring will generally lag snowmelt, except in regions with deep snow and no extreme cold where the soil may never really freeze.

Further analysis at other sites, and with a longer record from a new instrument will be necessary to fully evaluate the ability of this type of instrument to capture both the spring leaf-out of deciduous ecosystems and the onset of frost and snow in the autumn, which (along with shorter daylength) signal the end of the growing season [e.g., Larcher, 1993]. A more complete data set on snow, branch, bole, and leaf/needle temperatures, and on canopy and ground snowpack texture would lead to a clearer interpretation of both the variability of NSCAT during the winter and the ecosystem significance of the thaw signal in spring. A better understanding of the difference in the NSCAT signal between the northern and the southern sites will also be necessary to develop a robust freeze/thaw detection algorithm that accounts for the complete ensemble of vegetation and snow freeze/thaw effects.

Acknowledgments. This work was supported by grants from the NASA Terrestrial Ecology Program and the National Science Foundation Division of Polar Programs. Portions of the research described in this paper were carried out by the Jet Propulsion Laboratory, California Institute of Technology, under contract with the National Aeronautics and Space Administration. We thank Rob Braswell, Bill Salas, and Xiangming Xiao for helpful discussions, and two anonymous reviewers for helpful comments and suggestions.

\section{References}

Black, T.A. et al., Annual cycles of water vapour and carbon dioxide fluxes in and above a boreal aspen stand, Global Change Biol., 2, 219-229, 1996.

Blanken, P.D., T.A. Black, P.C. Yang, H.H. Neumann, Z. Nesic, R Staebler, G. den Hartog, M.D. Novak, and X. Lee, Energy balance and canopy conductance of a borcal aspen forest: Partitioning overstory and understory components, J. Geophys. Res., 102, 28,915-28,927, 1997.

Boehnke, K., and V. Wismann, Detecting soil thaw in Siberia with ERS scatterometer and SAR, in Proceedings of the 3rd ERS Symposium. on Space at the Service of our Environment, pp. 35-40, Eur. Space Agency, Florence, Italy, 1997.

Chen, J.M., P.M. Rich, S.T. Gowcr, J.M. Norman, and S. Plummer, Leaf area index of boreal forests: Theory, techniques, and measurements, J. Geophys. Res., 102, 29,429-29,444, 1997.

Colbeck, S.C., An overview of seasonal snow metamorphism, Rev. Geophys., 20, 45-61, 1982.

Dunbar, R.S., NASA scatterometer high-resolution merged geophysical data product user's guide, version 1.0, NASA Jet Propul. Lab. Rep., 1996.

Elachi, C., Introduction to the Physics and Techniques of Remote Sensing, 413 pp., John Wiley, New York, 1987.

Elliott-Fisk, D.L., The boreal forest, in North American Terrestrial Vegetation, edited by M.G. Barbour and D.W. Billings, pp. 33-62, Cambridge Univ. Press, New York, 1988.

Frolking, S., Sensitivity of spruce/moss borcal forest carbon balance to seasonal anomalics in weather, J. Geophys. Res., 102, 29,05329,064, 1997.

Frolking, $\mathrm{S}$, et al., Modelling temporal variability in the carbon balance of a spruce/moss boreal forcst, Global Change Biol., 2, 343-366, 1996.

Goulden, M.L., J.W. Munger, S.-M. Fan, B.C. Daubc, and S.C. Wofsy, $\mathrm{CO}_{2}$ exchange by a deciduous forcst: Response to interannual climate variability, Science, 271, 1576-1578, 1996.

Goulden, M.L., B.C. Daube, S.-M. Fan, D.J. Sutton, A. Bazzaz, J.W. Munger, and S.C. Wofsy, Physiological responses of a black spruce forest to weather, J. Geophys. Res., 102, 28,987-28,996, 1997.

Hall, D.K., M. Sturm, C.S. Benson, A.T.C. Chang, J.L. Foster, H. Garbeil, and E. Chacho, Passive microwave remote sensing and in situ measurements of arctic and subarctic snow covers in Alaska, Remote Sens. Environ., 38, 161-172, 1991. 
Hall, F.G., D.E. Knapp, and K.F. Huemmrich, Physically based classification and satellite mapping of biophysical characteristics in the southern boreal forest, J. Geophys. Res., 102, 29,567-29,580, 1997.

Jarvis, P.G., J.M. Massheder, S.E. Halc, J.B. Moncrieff, M. Rayment, and S.L. Scott, Seasonal variation of carbon dioxide, water vapor, and energy exchanges of a boreal black spruce forest, $J$. Geophys. Res., 102, 28,953-28,966, 1997.

Keeling, R.F., S.C. Piper, and M. Heimann, Global and hemispheric $\mathrm{CO}_{2}$ sinks deduced from changes in atmospheric $\mathrm{O}_{2}$ concentration, Nature, 381, 218-221, 1996.

Kennett, R.G., and F. Li, Seasat over-land scatterometer data, I, Global overview of the $K_{u}$-band backscatter coefficients, IEEE Trans. Geosci. Remote Sens., 25, 592-605, 1989.

Kimball, J.S., P.E. Thornton, M.A. White, and S.W. Running, Simulating forest productivity and surfacc-atmosphere carbon exchange in the BOREAS study region, Tree Physiol., 17, 589-599, 1997.

Kraszewski, A. (Ed.), Electromagnetic Wave Interaction With WaterContaining Materials, 484 pp., IEEE Press, Piscataway N. J., 1996.

Kunzi, K.F., S. Patil, and H. Rott, Snow-cover parameters retrieved from Nimbus-7 scanning multichannel microwave radiometer (SMMR) data, IEEE Trans. Geosci. Remote Sens., 20, 452-467, 1982.

Larcher, W., Physiological Plant Ecology, Springer-Verlag, 506 pp., New York, 1993.

Larsen, J.A., The Boreal Ecosystem, Academic, 500 pp., San Diego, Calif., 1980.

McDonald, K.C., J.S. Kimball, R. Zimmermann, J.B. Way, S.W. Running, and S. Frolking, Mapping seasonal freeze/thaw processes in Alaska with NSCAT, AGU Fall Meeting, Am. Geophys. Union, San Francisco, Calif., 1998.

Myneni R.B., Keeling C.D., Tucker C.J., Asrar G., Nemani R.R., Increased plant growth in the northern high latitudes from 19811991, Nature, 386, 698-702, 1997.

Naderi, F.M., M.H. Freilich, and D.G. Long, Spacebome radar measurement of wind velocity over the ocean-An overview of the NSCAT scatterometer system, Proc. IEEE, 79, 6, 1991.

Ranson, K.J., G. Sun, R.H. Land, N.S. Chauhan, R.J. Cacciola, and $O$. Kilic, Mapping of boreal forest biomass from spaceborne synthetic aperture radar, J. Geophys. Res., 102, 29,599-29,610, 1997.

Rignot, E., and J.B. Way, Monitoring freeze-thaw cycles along northsouth Alaskan transects using ERS-1 SAR, Remote Sens. Environ., 49, 131-137, 1994.

Rignot, E., J.B. Way, K. McDonald, L. Viereck, C. Williams, P. Adams, C. Payne, W. Wood, and J. Shi, Monitoring of environmental conditions in taiga forests using ERS-1 SAR, Remote Sens. Environ., 49, 145-154, 1994.
Saatchi, S.S., and E. Rignot, Classification of boreal forest cover types using SAR images, Remote Sens. Environ., 60, 270-281, 1997.

Sellers, P.J., et al., BOREAS in 1997: Experiment overview, scientific results, and future directions, J. Geophys. Res., 102, 28,731-28,770, 1997.

Shi, J., R.E. Davis, and J. Dozier, Stereological determination of drysnow parameters for discrete-scatterer microwave modeling, Ann. Glaciol., 17, 295-299, 1993.

Steyacrt, L.T., F.G. Hall, and T.R. Loveland, Land cover mapping, fire regeneration, and scaling studies in the Canadian boreal forest with 1 km AVHRR and Landsat TM data, J. Geophys. Res., 102, 29,58129,598, 1997.

Tsai, W., J. Graf, C. Winn, J. Huddleston, S. Dunbar, M. Freilich, F. Wentz, D. Long, and L. Jones, Post-launch sensor verification and calibration of the NASA scatterometer, IEEE Trans. Geosci. Remote Sens., in press, 1999.

Ulaby, F.T., R.K. Moore, and A.K. Fung, Microwave Remote Sensing-Active and Passive, pp. 457-1064, vol. II, Artech Housc, Norwood, Mass., 1982.

Wankiewicz, A., Multi-temporal microwave satellite observations of snowpacks, Ann. Glaciol., 17, 155-160, 1993.

Way, J.B., E. Rignot, R. Oren, R. Kwok, K. McDonald, M.C. Dobson, G. Bonan, L. Viereck, and J.E. Roth, Evaluating the type and state of Alaskan taiga forests with imaging radar to use in ecosystem flux models, IEEE Trans. Geosci. Remote Sens., 32, 353-370, 1994.

Way, J.B., R. Zimmermann, E. Rignot, K. McDonald, and R. Oren, Winter and spring thaw as observed with imaging radar at BOREAS, J. Geophys. Res. 102, 29,673-29,684, 1997.

Wegmuller, U., The effect of freezing and thawing on the microwave signatures of bare soil, Remote Sens. Environ., 33, 123-135, 1990.

S. Frolking, Institute for the Study of Earth, Occans, and Space, Morse Hall, University of Ncw Hampshire, Durham, NH 03824-3525. (e-mail: steve.frolking@unh.edu).

J.S. Kimball, S.W. Running, NTSG, University of Montana, Missoula MT, 59812 (e-mail: johnk@ntsg.umt.edu; swr@ntsg.umt.cdu).

K.C. McDonald, J.B. Way, Jet Propulsion Laboratory, California Institute of Technology, Pasadena, CA 91109 (c-mail: kylc.mcdonald@.jpl.nasa.gov; way@lor.jpl.nasa.gov).

R. Zimmermann, Bitöek, U. Bayreuth, Bayreuth, D-95540 Germany (e-mail: reiner.zimmermann@bitoek.uni-bayreuth.de).

(Received July 27, 1998; revised November 2, 1998; accepted November 10, 1998.) 